\title{
THE HALPERN TRANSFORMATION: SAME-SeX MARriage, Civil SOCIETY, AND THE LIMITS OF LIBERAL LAW
}

\author{
F.C. DECOSTE*
}

Law's attitude is constructive: it aims ... to lay principle over practice to show the best route to a better future, keeping the right faith with the past.

- Ronald Dworkin ${ }^{1}$

[T] he authority of law [is] the maintenance of the community's past.

- Paul W. Kahn ${ }^{2}$

Freedom is located in the realm of the social....

- Hannah Arendt ${ }^{3}$

\section{INTRODUCTION}

The geography to the destination in Halpern v. Canada (A.G. $)^{4}$ is simple enough: (a) there exists a common law rule which at once prescribes that marriage is a heterosexual union and that therefore bars same-sex marriage; ${ }^{5}$ (b) this rule distinguishes between heterosexual and homosexual couples because it denies the latter access to the regulatory regimes that govern and constitute marriage at law ${ }^{6}$ and (c) this distinction is discriminatory and violative of the equality rights of homosexuals provided by s.15(1) of the Canadian Charter of Rights and Freedoms. ${ }^{7}$ This must be so because sexual orientation is an analogous ground under $\mathrm{s}$. $15(1),{ }^{8}$ because equality protects and expresses human dignity, ${ }^{9}$ because dignity is violated when the person/claimant who is subject to differential treatment on an enumerated or analogous ground reasonably feels that his or her dignity is demeaned by that treatment, ${ }^{10}$ and

\section{Professor, Faculty of Law, University of Alberta.}

Ronald Dworkin, Law's Empire (Cambridge, MA: Belknap Press, 1986) at 413.

Paul W. Kahn, The Cultural Study of Law: Reconstructing Legal Scholarship (Chicago: University of Chicago Press, 1999) at 46.

$3 \quad$ Hannah Arendt, The Human Condition (New York: Doubleday Anchor, 1959) at 29.

4 (2003), 225 D.L.R. (4th) 529 (Ont. C.A.) [Halpern]. This route was also travelled by the British Columbia Court of Appeal in EGALE Canada v. Canada (A.G.) (2003), 255 D.L.R. (4th) 472 [EGALE] and by the Quebec Superior Court in Hendricks c. Québec (P.G.), (2003), J.E. 2003-466 [Hendricks] (presently before the Quebec Court of Appeal).

Halpern, ibid. at paras. 1, 37.

Ibid. at paras. 2, 69.

Part I of the Constitution Act, 1982, being Schedule B to the Canada Act 1982 (U.K.), 1982 [Charter]. Ibid. at para. 7.

Ibid. at para. 60.

Ibid. at para. 78. 
because a person/claimant will meet that test when, as here, " he or she can prove, having regard to "the individual's or group's traits, history, and circumstances,"12 that the effect of the treatment is to perpetuate or to promote "the view that the individual is less capable, or less worthy of recognition or value as a human being or as a member of Canadian society." 13 Simple too, at least facially, is the character of that destination: that confining marriage to men and women unreasonably infringes the equality rights of homosexuals and is therefore constitutionally unacceptable in a free and democratic society such as Canada. In the result, marriage must be "reformulate[d] ... as 'the voluntary union for life of two persons to the exclusion of all others." "14

More complex, and certainly more intriguing, is how such an unusual ${ }^{15}$ destination became at all possible. In attempting to answer this question - and the question of consequences that attends it - this comment will not concern itself at any length with the constitutional jurisprudence in which the Halpern Court wraps its transformation of the institution of marriage. ${ }^{16}$ Instead, my primary concern will be whether such a destination is properly available to a liberal state. I shall argue that it is not on grounds that, properly conceived, the relationship of a liberal state to the standing institutions and traditions of civil society forbids it. I shall also argue that the effect of this decision, and others like it, ${ }^{17}$ is, on the one hand, to wrench the discourse of rights and of constitutionalism more generally out of the liberal framework on which the credentials of each singularly depends and, on the other, to elevate the state, at its sole discretion, to the illiberal position of manager, colonizer, and conqueror of civil society.

In Part II, I shall explore the points of the decision that both permitted the Court its innovation and shielded it from the normative matter on which, in my view, the issue in

Ibid. at para. 94: "Denying same-sex couples the right to marry perpetuates the contrary view, namely, that same-sex couples are not capable of forming loving and lasting relationships, and thus same-sex relationships are not worthy of the same respect and recognition as opposite-sex relationships." Ibid. at paras. 79.

13 Ibid. at para. 80, citing Law v. Canada (Minister of Employment and Immigration), [1999] 1 S.C.R. 497 at 535.

Ibid. at para. 148. The Court must here have meant natural persons, since otherwise it would be condoning the marriage of corporations and other unnatural legal persons.

15 And unusual it is: prior to Halpern, only two countries - Belgium and the Netherlands - recognized same-sex unions as marriage (though both, now unlike Canada, have residency requirements); and the Netherlands alone accorded same-sex marriage the same rights and obligations accorded to opposite-sex marriage. A number of European countries (Denmark, Norway, Sweden, Iceland, Finland, Hungary, France, Germany, and Portugal), several American states (Vermont, California, and Hawaii), and four Canadian provinces (Nova Scotia, Quebec, Saskatchewan and Alberta) have enacted laws that, in different ways, permit same-sex couples to enter into registered partnerships or civil unions, but none of these accords all of the rights accorded to marriage. See Katharina Boele-Woelki \& Angelike Fuchs, eds., Legal Recognition of Same-Sex Couples in Europe (Antwerp: Intersentia, 2003); Robert Wintemute \& Mads Andenaes, eds., Legal Recognition of Same-Sex Partnerships: A Study of National, European and International Law (Oxford: Hart, 2001); "Developments in the Law - The Law of Marriage and Family" (2003) 116 Harvard L. Rev. 1996 at 2004-27; online: Lamda Legal $<w w w . l a m b d a l e g a l . o r g / c g i-b i n / i o w a / d o c u m e n t s /$ record? $=403>$; and online: Rutgers School of Law: Pathfinder Series <www.rci.rutgers.edu/ axellute/ssm.htm>. namely, the Supreme Court of Canada decisions in Egan v. Canada, [1995] 2 S.C.R. 513, Vriend v. Alberta, [1998] 1 S.C.R. 493, and M. v. H., [1999] 2 S.C.R. 3. 
Halpern properly depends, namely, the limits of authority of the liberal state as regards civil society. Two matters are critical in these regards: the Court's (mis)interpretation of the common law of marriage (which permitted it to elide the distinction between the constitution and the recognition of social practices) and its (mis)understanding of marriage (which permitted it to ignore the sexed and gendered nature of marriage). In Part III, I hope briefly to dispatch two canards that very often misdirect debate about the legal propriety of same-sex marriage, namely, that the matter properly falls to the legislative branch and that the incapacity of homosexuals to marry one another is analogous to incapacity on grounds of race. With this background in place, Part IV will convey the meat of my case against the legal recognition of same-sex unions as marriage and against the performance of the Canadian state in Halpern which, because it mistakes dirigiste social engineering for liberal statecraft, must be condemned as a failure of political morality. In a brief conclusion, I shall dwell on the overall significance of the state's performance in Halpern as regards both marriage and the practices of liberal governance in Canada, on the tone and temper of the judgment itself, and on the nature of a properly liberal response to the question of same-sex unions.

\section{MisconCEPTIONS}

\section{A. The LAW OF MarRiage}

To make marriage muster to constitutional command, it fell to the Court to rummage around in legal history to find something, anything, that might make of marriage a legal artefact, a convention "prescribed by law." ${ }^{8}$ But the Court did not rummage deeply enough, nor did it read what it did find at all properly.

Had this Court undertaken seriously the enterprise of uncovering the history of the law's attitude to marriage, it might have begun with the classics of our legal tradition - with Bracton, ${ }^{19}$ Fortescue, ${ }^{20}$ Coke, ${ }^{21}$ and Blackstone. ${ }^{22} \mathrm{Had}$ it done so, it would have been immediately struck by this: though each of these commentaries on the Anglo-American legal tradition deals with marriage, none of them defines marriage, either on its own initiative or by way of reporting judicial determinations of the matter. Instead, each deals with the rights and obligations attaching to the status of "husband" and "wife"23 (a matter which will be of concern when this comment turns its attention to the Court's understanding of marriage), and in so doing, with the doctrines of unity and consortium that together defined the nature and content of the marital relationship at common law. So informed, the Court might have been moved to ask how works so central to our law would miss a definition so elemental to the Court's own project in Halpern.

Halpern, supra note 4 at para. 110 (see also paras. 35-37).

Henry de Bracton, On the Laws and Customs of England, (circa 1236) trans. by Samuel E. Thorne (Cambridge, MA: Belknap Press, 1968-1977).

Sir John Fortescue, On the Laws and Governance of England, (circa 1470) ed. by Shelley Lockwood (New York: Cambridge University Press, 1997).

Sir Edward Coke, Institutes of the Laws of England, $(1628,1642,1644)$ (London: W. Clarke \& Sons, 1817).

Sir William Blackstone, Commentaries on the Laws of England, (1765-1769) (Chicago: University of Chicago Press, 1979).

These and other terms appear here in quotations as a means of emphasizing their importance to the general discourse on same-sex unions. 
The Court might then also have been moved to inquire into the history of the state's relationship with marriage. Had it done so, it would have discovered that the state came late to marriage. Indeed, it was not until 1753, with the passage of Lord Hardwicke's Marriage $A c t$, that the state finally became a significant player in the coming together of its citizens through marriage. ${ }^{24}$ Had the Court then traced the history of the state's subsequent involvement, it would have become clear that, like the common law commentators, the state, until just recently, ${ }^{25}$ found it never necessary to define marriage legislatively. Rather, as did they, the state simply assumed that marriage had a plain and common meaning in legal and cultural commerce.

With the produce of these inquiries at hand, the Court would have placed itself to deal competently with the decision in Hydev. Hyde and Woodmansee ${ }^{26}$ the 1866 House of Lords decision on which the whole of its subsequent enterprise depends. It would have first thought it an historical oddity - here and nowhere else in our law is marriage defined - and, on that account alone, been moved both to explain and to situate the definition.

On the history of marriage as it relates to the attempts, successively, of the church and state somehow to regulate the matter, see Lawrence Stone, The Family, Sex and Marriage in England 1500-1800, abr. ed. (London: Penguin, 1979), esp. 29-34; John R. Gillis, For Better, For Worse: British Marriages 1600 to the Present (Oxford: Oxford University Press, 1985), esp. 17-21, 88-89; Michael M. Sheehan, Marriage, Family, and Law in Medieval Europe: Collected Studies (Toronto: University of Toronto Press, 1996); Diana Leonard Barker, "The Regulation of Marriage: Repressive Benevolence" in Gary Littlejohn et al., eds., Power and the State (London: Croom Helm, 1978) 239; Mary Lyndon Shanley, "Review Essay: The History of the Family in Modern England" (1979), 4 Signs 740; and Frederick Pollock \& Frederic William Maitland, The History of English Law Before the Time of Edward I, Vol. VII (London: Cambridge University Press, 1968) Chp. VII. Since it is sometimes thought that the Church's involvement in marriage and the sacramental status of marriage raise issues relevant to the same-sex marriage debate, it is perhaps worth noting that this involvement and this status are, no less than the state, also relative latecomers to marriage. "It was not until the thirteenth century that the Church at last managed to take control of marriage law"; marriage was not "elevated to the position of a sacrament until 1439"; and "it was only in 1563, after the Reformation, that the Catholic Church first required the presence of a priest for a valid and binding marriage" (Stone, ibid. at 30 ). See also Harold J. Berman, Law and Revolution: The Formation of the Western Legal Tradition (Cambridge, MA: Harvard University Press, 1983) c. 6.

With, and of course in response to, the emergence of the same-sex marriage issue. In Canada, this response took shape in Bill C-23, An Act to modernize the Statutes of Canada in relation to benefits and obligations [now: Modernization of Benefits and Obligations Act, S.C. 2000, c.12] s. 1.1 of which reads as follows: "for greater certainty, the amendments made by this Act do not affect the meaning of the word 'marriage,' that is, the lawful union of one man and one woman to the exclusion of all others." In America, the response, beginning in 1996 with the federal Defense of Marriage Act [110 Stat. 2419 (1996)] and subsequently in the majority of states, has taken the form of separate legislation to protect the heterosexual nature of marriage. For instance, s. 3(a)(7) of that $A c t$ reads:

In determining the meaning of any Act of Congress, or of any ruling, regulation, or interpretation of the various administrative bureaus and agencies of the United States, the word "marriage" means only a legal union between one man and one woman as husband and wife, and the word "spouse" refers only to a person of the opposite sex who is a husband or a wife.

Two things are noteworthy about these initiatives: first, that their necessity is only intelligible in terms of a legal history that simply assumed the common social meaning of marriage; and second, that each aims not to prescribe a new meaning, but to preserve that ancient one. Concerning the Canadian initiative, it must now be added that, despite the unity of Parliament and Senate on the matter, the federal Executive has now moved, in response to Halpern - through the reference to the Supreme Court of its Proposal for an Act respecting certain aspects of legal capacity for marriage for civil purposes - to define marriage as "the lawful union of two persons to the exclusion of all others." See online: Department of Justice, Canada <www.canada.justice.gc.ca/en/news/nr/2003/doc_30946.html>. (1866), LR 1 P\&D 130 [Hyde]. 
Hyde concerned whether a party to a polygamous marriage contracted in a foreign jurisdiction (in that case, Utah) was entitled to matrimonial relief or to a declaration as to the validity of the marriage in the English courts under the Divorce Act then governing those matters in England. The Court in Hyde answered negatively in both regards and that answer remained the rule in Hyde until abolished by statute. ${ }^{27}$ En passant, the Court delivered itself of the following opinion on the nature of marriage, with which, in part (here italicized), the Halpern Court begins its judgment: ${ }^{28}$

What then is the nature of this institution as it is understood in Christendom? Its incidents vary in different nations; but what are its essential elements and invariable features? If it be of common acceptance and existence, it must needs (however varied in different countries in its minor incidents) have some prevailing identity and universal basis. I conceive that marriage, as understood in Christendom, may for this purpose be defined as the voluntary union for life of one man and one woman, to the exclusion of all others. ${ }^{29}$

Since the fact at issue in Hyde was polygamy and not heterosexuality, on a strict reading of the case, the definition is obiter as regards the latter (as some proponents of same-sex marriage have rightly argued ${ }^{30}$ ). But my concern with the Halpern Court's interpretation of Hyde concerns another, much more important matter.

Properly read, the so-called rule in Hyde is no rule at all, simply because what the Court is about in Hyde, and expressly so, is not prescription, but recognition. That is, the Court was undertaking not to define marriage, but to recognize what in societies such as ours constitutes the form of life, the "institution," ${ }^{31}$ we know as marriage. ${ }^{32}$ Moreover, that "the laws ... throw about" that form of life "a variety of legal incidents" is then secondary to the recognition of it as something beyond and antecedent to the law. ${ }^{33}$ The Hyde Court, then, did not claim sovereignty over marriage, and even less, did it conflate marriage as cultural practice with the law of marriage. ${ }^{34}$ Instead, the Court thought the law and its own governance epiphenomenal, as each responses to, and not productive of, the independent cultural practice we know as marriage. And with this, the oddity of the definition is resolved: the Hyde Court, per force of the issue before it simply made plain what the commentators had no need to make plain, but no less than the Court recognized - namely, that marriage is a form of life to which the law in certain measure responds, but which it does not itself create.

More specifically, by s. 47 of The Matrimonial Causes Act 1973 (U.K.), 1973, c. 18.

Halpern, supra note 4 at para. 1.

Hyde, supra note 26 at 133 [emphasis added].

See e.g. Julie C. Lloyd, "Defining Marriage, Step One: EGALE v. Canada" (2002) 39 Alta. L. Rev. 963 at 968 . Remarkably, given that theirs was a Charter complaint and required some rule which could be made to pass constitutional muster, the first submission of the plaintiffs in Halpern was that "there is no common law bar to same-sex marriages" because, inter alia, the Hyde definition is obiter in so far as it applies to sexuality (Halpern, supra note 4 at para. 35). For the Halpern Court's not-veryconvincing rejection of these arguments, see $i b i d$. at para. 37.

Hyde, supra note 26 at 133.

Ibid. That the Court uses the word "Christendom" for this is of no consequence.

Ibid.

To sample the ongoing debate concerning whether marriage and family exist independently from law, see Laurence D. Houlgate, "Must the Personal be Political? Family Law and the Concept of Family" (1998) 12 Int'l J.L. Pol'y \& Fam. 107; Teresa Stanton Collett, "Recognizing Same-Sex Marriage: Asking for the Impossible?" (1998) 47 Catholic U.L. Rev. 1245; and David Orgon Coolidge, "SameSex Marriage? Baehr v. Miike and the Meaning of Marriage" (1997) 38 S. Texas L. Rev. 1. 
Though the Attorney General of Canada ceded that Hyde established a legal rule, ${ }^{35}$ it nonetheless placed before the Court, as part of its submissions on s. 15(1) of the Charter, an argument similar in certain respects to mine here. As reported by the Court:

The AGC submits that marriage, as an institution, does not produce a distinction between opposite-sex and same-sex couples. The word "marriage" is a descriptor of a unique opposite-sex bond that is common across different times, cultures and religions as a virtually universal norm. Marriage is not a common law concept; rather, it is a historical and worldwide institution that pre-dates our legal framework. The Canadian common law captured the definition of marriage by attaching benefits and obligations to the marriage relationship. Accordingly, it is not the definition of marriage itself that is the source of the differential treatment. Rather, the individual pieces of legislation that provide the authority for the distribution of government benefits and obligations are the source of the differential treatment. Moreover, since the enactment of the Modernization of Benefits and Obligations Act, same-sex couples receive substantive equal benefit and protection of the federal law. ${ }^{36}$

Now, I have no desire to pass judgment on the quality of this argument, though my assessment of it should become clear by the end of this essay. Nor do I think it important to dissect the Court's reasoning in rejecting it. What I should like to pursue, rather, is the Court's understanding of the relationship between the law of marriage and the cultural practice of marriage, since it is that which matters most both to the outcome in Halpern and the course of my forthcoming argument about the limits of law.

At one point, the Court opines that, in its view, "[m]arriage is a legal institution, as well as a religious and a social institution." ${ }^{37}$ It then declares, first, that " $[t]$ his case is solely about the legal institution of marriage" and second, that "[i]t is not about the religious validity or invalidity of various forms of marriage." ${ }^{38}$ But, off-handed comments like "[n]o one is disputing that marriage is a fundamental societal institution" aside, ${ }^{39}$ the Court nowhere engages either the social or the relationship that ought properly to obtain between it and the state. By eliding the meaning and significance of marriage as cultural practice and as an object of state interest in this fashion, the Court consigns the whole of that part of social life to its governance. Thus can it elsewhere proclaim that "'marriage' does not have a constitutionally" - I here read "legal" - "fixed meaning" and that "like the term "banking' and the phrase 'criminal' law, the term 'marriage' ... has the constitutional flexibility necessary to meet changing realities of Canadian society" - as, of course, those needs are divined by the judiciary. ${ }^{40}$

The linchpin of this judicial imperialism resides in the Court's response to the aforementioned submission of the Attorney General of Canada. By declaring "irrelevant" "[t]he fact that the common law adopted, rather than invented, the opposite-sex feature of marriage, ${ }^{, 41}$ the Halpern Court erects a barrier between the social and the legal that, should 
it ever be passed, subordinates the social to the legal. This becomes clear when the Court next proclaims that because "Canadian governments chose to give legal recognition to marriage," ${ }^{42}$ judicial supervision of this cultural practice necessarily follows. Now, to make it plain, to argue thus is to display an impoverished legal sense and sensibility. Though my full argument to this assessment must await Part IV, suffice it here to say that by obliterating the crucial distinction between creation and recognition, the Court is holding the nature of the relationship that ought properly to obtain between liberal polity and liberal community hostage to its claim of sovereignty.

\section{B. The MEaning OF MarRiage}

The Halpern Court finds a second mandate for its re-manufacture of marriage in its understanding of marriage. Notwithstanding the claim that its concern is exclusively "the legal institution of marriage, ${ }^{, 43}$ the Court ignores entirely the law of marriage and puts in its place a certain cultural understanding of marriage then paraded as law. Let me explain.

Social practices are only intelligible in terms of their "point,"44 and any given practice can only (continue to) exist if its practitioners or participants are seized of some "sense"45 of the overall point of the "form of life" ${ }^{46}$ which the practice brings into the world. Marriage is a social practice that in life and subsequently, in law, has a point that constitutes it as a distinct practice. The point of marriage is the bestowal of a certain status on those who choose and are otherwise capable of entering into it and the creation of relations between them. ${ }^{47}$ The status bestowed by marriage is that of "wife" and "husband," and the relation between husband and wife is the form of life that marriage alone creates and of which it alone is the practice. Unless, as Orwell feared ${ }^{48}$ (and the Halpern Court appears to think ${ }^{49}$ ), words can themselves be bestowed any meaning and so manipulated endlessly, tradition, practice, and common understanding notwithstanding, then the statuses that constitute the point and contribution of marriage make of it an inherently heterosexual practice. To make it plain: on pain of either nonsense or self-serving delusion, marriage as an institutional practice is deeply, irretrievably, and oppositely-sexed, just because it is the practice of men and women uniting as husbands and wives. ${ }^{50}$ This is its nature precisely because of the nature of the

$42 \quad$ Ibid. at para. 69.

$43 \quad$ Ibid. at para 53

44 Dworkin, supra note 1 at 46-48, 50-51, 63-68, 70-73.

45 Alasdair MacIntyre, After Virtue: A Study in Moral Theory (Notre Dame: University of Notre Dame Press, 1984) c. 15, esp. 221-23.

46 Dworkin, supra note 1 at 63.

47 For a summary of the common law reception of the status of "husband" and "wife," see Pollock $\&$ Maitland, supra note 24 at 399-436.

48 George Orwell, "Politics and the English Language" in George Orwell, Collected Essays, 2d ed. (London: Secker \& Warburg, 1961) 353.

Supra note 40 and accompanying text.

Some proponents of same-sex marriage claim that history, especially ancient and early European history, provides evidence of the recognition of same-sex unions as marriage that contradicts what I am here claiming to be both the essence and common understanding of marriage as a social practice. For instance, William N. Eskridge devotes the second chapter of his widely influential The Case for SameSex Marriage: From Sexual Liberty to Civilized Commitment (New York: Free Press, 1996) to "A History of Same-Sex Marriage" [Eskridge relies in no mean measure on John Boswell, Same-Sex Unions in Pre-Modern Europe (New York: Villard Books, 1994)]. Though I cannot pursue this claim 
statuses it bestows and not because of any function, procreation especially, that some $\mathrm{s}^{51}$ may wish to associate with them.

The Halpern Court need have looked no further than $H y d e^{52}$ for evidence at law of this understanding of marriage. As put by the Court:

Marriage has been well said to be something more than a contract, either religious or civil - to be an Institution. It creates mutual rights and obligations, as all contracts do, but beyond that it confers a status. The position or status of "husband" and "wife" is a recognized one throughout Christendom: the laws of all Christian nations throw about that status a variety of legal incidents during the lives of the parties, and induce definite lights upon their offspring. ${ }^{53}$

Now, though the Ontario Court of Appeal otherwise pays the Court in Hyde much regard it is there after all that it found the 'rule' on which its entire enterprise depends - it pays no heed at all to the latter's speech about marriage as "[i]nstitution and status" 54 or about "the

at any length here, I do think it both inaccurate historically and inapposite normatively. So far as accuracy is concerned, arguments of the kind marshalled by Eskridge tend to conflate same-sex unions (the historical reality of which, of course, no one does, or could, deny) with marriage and, to the extent that they do, they suffer from special pleading. Take, for example, the following slippery passage:

I shall use the phrase same-sex union to refer to any kind of culturally or legally tolerated institution whereby individuals of the same sex are bonded together in relationships for reasons of affinity, economy, or society.... I am not using the term marriage casually. Although some ... same-sex relationships ... have marriage-like features, I do not always deem them same-sex marriages. The term is used only when it appears that the same-sex union was treated by contemporaries and legal authorities as about the same as different-sex marriage and met one or more of the civilizing functions of marriage, namely, long-term emotional support and bonding between the couple; economic security and division of labor in the household; or legitimacy and support of a family, including children.

(Ibid. at 16-17 [emphasis in original]). What is missing here (and, as we shall see in a moment, in Halpern as well), is any mention of the opposite-sexed statuses "husband" and "wife," in ancient times as well as now, as the cultural and legal core of marriage. And it is this elision that makes Eskridge's argument, and others like it, a special pleading bred of sleight of definitional hand.

More importantly, the argument has no purchase normatively. Remarkably, Eskridge elsewhere (ibid. at 91) appears to recognize this: "The more difficult claim to refute is the normative one, that marriage ought to be different-sex by definition." But, in that event, any counter-argument of this normative sort will itself have purchase only if it confronts, and never if it seeks merely to elide, the opposite-sexed status subjects of marriage, the "husband" and "wife." Eskridge's own normative argument - that "the dominant goal of marriage is and should be unitive, the spiritual and personal union of the committed couple" (which incidentally he marshals against what he takes - wrongly in my view - to be the main normative argument on the other side, namely, that marriage is and ought to be "procreative") - fails to meet this test since it simply defines away the status subjects "husband" and "wife."

On homosexuality, law, and marriage in early history, see e.g. Thomas K. Hubbard, ed., Homosexuality in Greece and Rome: A Source Book of Basic Documents (Berkeley: University of California Press, 2003); Sara Elise Phang, The Marriage of Roman Soldiers (13 B.C.-A.D. 235): Law and Family in the Imperial Army (Leiden: Brill, 2001); Judith Evans Grubbs, Law and Family in Late Antiquity: The Emperor Constantine's Marriage Legislation (Oxford: Clarendon Press, 1995); Wayne R. Dynes \& Stephen Donaldson, eds., Homosexuality in the Ancient World (New York: Garland, 1992); and Percy Ellwood Corbett, The Roman Law of Marriage (Oxford: Clarendon Press, 1930). Remarkably, in Halpern, the Attorney General of Canada, supra note 4 at paras. 89, 118, 120-23. Supra note 26.

Ibid. at 133.

Ibid. 
duties which it is the office of the marriage law in this country to assert and enforce." 55 Just the contrary: in the whole of its judgment, the Halpern Court not once utters or otherwise refers to the words "husband" or "wife," nor does it conceive of marriage in terms of status. What we are offered instead is a law of marriage so reformulated and redesigned that, contrary apparently to the Court's own understanding, the institution and the law that recognized it are each "abolished." 56

It is the Halpern Court's understanding of marriage which makes good its refusal to recognize both the status-conferring nature of marriage as institution and the sexed nature of the status that it confers. In the place of men and women, the Court offers as the subjects of marriage what it terms "conjugal couples" ${ }^{157}$ which are, in its view, ${ }^{58}$ either "same-sex" "opposite-sex." In the place of marriage as the bestowal of status, the Court construes marriage as the expression and recognition of "love and commitment". 61

\begin{abstract}
Marriage is, without dispute, one of the most significant forms of personal relationships. ... Through the institution of marriage, individuals can publicly express their love and commitment to each other. Through this institution, society publicly recognizes expressions of love and commitment between individuals, granting them respect and legitimacy as a couple. This public recognition and sanction of marital relationships reflect society's approbation of the personal hopes, desires and aspirations that underlie loving, committed conjugal relationships. This can only enhance an individual's sense of self-worth and dignity. ${ }^{62}$
\end{abstract}

With this, the Court subscribes to what has been variously termed the "romantic love" view of marriage ${ }^{63}$ the "conjugal myth," ${ }^{64}$ and, more recently, "the postmodern model of marriage." ${ }^{65}$ Whatever it is called, the effect is plain: marriage no longer has anything at all to do with the bestowal of a status which makes possible relations which, in the absence of the status, are unavailable in our lifeworld. Instead, marriage now has to do with the recognition and endorsement of pre-existing dispositions and relations. So viewed, marriage adds nothing to human possibility and, is as a result, de-institutionalized.

As do non-judicial proponents, ${ }^{66}$ the Halpern Court seeks to redefine marriage as a committed relationship in order to make possible their ambition of extending marriage to

Ibid. at 138 .

Halpern, supra note 4 at para. 129: "The Couples are not seeking to abolish the institution of marriage; they are seeking access to it."

Ibid. at para. 2.

Whether this word de-sexes marriage is contestable since the English word "conjugal" seems itself, both in origin and in usage, to mean the joining of husband and wife (Oxford English Dictionary, 2d ed., s.v. "conjugal").

Halpern, supra note 4 at para. 1 (citing to the term's first appearance in the judgment).

Ibid. at para. 36 (citing to the term's first appearance in the judgment).

Ibid. at para. 5.

Ibid.

See Stone, supra note 24 at 189-91.

See Gillis, supra note 24 at 3-5, 313-16.

See Coolidge, supra note 34 at 38-42.

See e.g. Eskridge, supra note 50 at 70-74, 82, 91, 98-104, 111-13, 129, 210; Andrew Sullivan, Virtually Normal: An Argument about Homosexuality (New York: Alfred A. Knopf, 1995) at 179; and Richard D. Mohr, "The Case for Gay Marriage" (1995), 9 Notre Dame J. L. Ethics \& Pub. Pol'y 215 at 226-27. 
same-sex persons. Indeed, the similarities between the two, between the commentators and the judges, is nothing less than remarkable. Here is how Andrew Sullivan puts the case:

Marriage is not simply a private contract; it is a social and public recognition of a private commitment. As such, it is the highest public recognition of personal integrity. Denying it to homosexuals is the most public affront possible to their public equality.... Until gay marriage is legalized, this fundamental element of personal dignity will be denied a whole segment of humanity. No other change can achieve it. ${ }^{67}$

The Court in Halpern very nearly parses this. Straightaway, we are told that "this case is ultimately about the recognition and protection of human dignity and equality in the context of the social structures available to conjugal couples in Canada."68 Elsewhere, we are informed that "whether same-sex couples can marry is a matter of capacity" 69 and that, citing the Supreme Court of Canada decision in $L a w,{ }^{70}$ "[h] hman dignity is harmed by unfair treatment premised upon personal traits or circumstances which do not relate to individual needs, capacities, or merits." ${ }^{71}$ The Court in this fashion leads us to what, given not only these premises but, critically, the banishment of status from marriage by definitional fiat, is then inevitable: that "the common law requirement that marriage be between persons of the opposite sex does not accord with the needs, capacities and circumstances of same-sex couples"; 72 that "the dignity of persons in same-sex relationships is violated by the exclusion of same-sex couples from the institution of marriage" view that same-sex relationships are less worthy of recognition than opposite-sex relationships"74); and that "the common law definition of marriage ... violates s. 15(1) of the Charter."75

All of this, the judges' reasoning no less than the academic argument, is only made possible by ignoring, by defining away, the meaning of marriage at law and as cultural practice, namely, that marriage is a practice that creates a specific, sexed form of life, the form of life that subsists in the relationship, not otherwise extant, between husband and wife. Only once this understanding is banished does the inability of homosexuals to marry one another - like everyone else they can marry persons of the opposite sex - become a matter that goes to equality and not to (in)capacity. Only thus, by elevating incapacity to inequality through editing out status, culturally and legally, does the entire structure of this judgment and of the gay marriage movement more generally have any coherence. But, as I shall argue in Part IV, the price of this coherence and structure is nothing less than the abandonment of the very principles that ought to govern the conduct of a liberal, democratic state.

Sullivan, ibid. at 179, 184.

Halpern, supra note 4 at para. 2.

Ibid. at para. 41.

Supra note 13 at 530 (per Iacobucci J.).

Halpern, supra note 4 at para. 3 [emphasis added].

Ibid. at para. 95 [emphasis added].

Ibid. at para. 108.

Ibid. at para. 107.

Ibid. at para. 108. 


\section{MisDiReCtions}

We come now to the two previously mentioned canards that so very often misdirect discussion of same-sex marriage. Discrediting these two is important not just because they cloud debate, but also because of the manner in which they breed this confusion. Each calls upon certain of our settled moral/political convictions. Typically, the argument from parliamentary competence calls upon our democratic sensibilities in order to enlist our opposition to same-sex marriage, whereas the argument from racial analogy calls upon our commitment to equality (and our abhorrence of racism) to enlist our allegiance to same-sex marriage. However, because neither argument is coherent, in the final analysis, each is a manipulation that deserves our disdain rather than our assent.

\section{A. ARgument For THE COMPETENCE OF THE Legislative BRANCH}

This argument, rehearsed in the print media time and again since Halpern was handed down ${ }^{76}$ goes something like this: there are certain matters, sometimes referred to as "moral issues," other times as "policy issues," that in a democratic state fall not to the courts, but to the people's elected representatives in Parliament. As applied to the same-sex marriage issue, the argument instructs that any change to the legal definition of marriage is a matter exclusively for the legislative branch, where after motion and debate the question will be answered in whichever fashion and to whatever ends the majority determines.

The political metaphysics of this argument must reside in some understanding of parliamentary sovereignty. But in that event it must be said that the best view of that matter lends the argument no support whatsoever. Dicey's parliamentary sovereignty does not afford parliament license to do anything it wishes on any matter. ${ }^{77}$ Though it is his understanding that parliament has "the right to make or unmake any law whatever," ${ }^{78}$ he cabins that authority by defining law as "any rule which will be enforced by the Courts."79 This caveat ties sovereignty to Dicey's conception of the Rule of Law, which has as its aim "the absence of arbitrary power" by all branches of the state ${ }^{80}$ and is characterized by what Dicey terms "the predominance of the legal spirit"81 - the disposition of public institutions to acknowledge the limits of their authority.

76 See e.g. Gordon Gibson, "I care who writes the nation's laws" National Post (12 June 2003) Al8; David Warren, "Canada's courts now rule the country" National Post (22 June 2003) A12; Stephen Harper, "A dangerous precedent for how Canada is run" National Post (21 July 2003) A18; and Jeffrey Simpson, "Why don't we just turn policy over to the courts?" The Globe and Mail (22 July 2003) A15. 1915).

$78 \quad$ Ibid. at 38.

79 Ibid. This caveat is the linchpin of a proper understanding not only of Dicey's view of parliamentary sovereignty, but of his view of Anglo-constitutionalism overall which, surely to the dismay of purveyors of the present argument, he defines as "a judge-made constitution" (though with eminent good sense, he then qualifies: "and it bears on its face all the features, good and bad, of judge-made law") (ibid. at 192).

80 Ibid. at 185: "the absence of arbitrary power on part of the Crown, of the executive, and of every other authority in England."

81 Ibid. at 191. 
The argument from competence misses all of this, and proceeds instead from the view that any and all aspects of human life are properly and possibly prey to the aims and manipulations of legislation. The implications of such a view are invidious indeed. For then the Rule of Law becomes in its entirety rule by law, and nothing is beyond law's reach. Happily, such is not the instruction of our law. ${ }^{82}$ Our law is a tradition and site of contestation about the limits of the authority of the state, in all of its branches, ${ }^{83}$ to regulate our lives our actions, our ambitions and preferences, and our associations. To the extent that the argument from sovereignty recoils from this understanding, its instruction is beyond any proper point, and it ought not therefore be accorded any purchase in our reflections about same-sex marriage or, for that matter, any other issue towards which it is directed.

\section{B. ARGUMENT From the RACIAL ANALOGY}

This analogy suggests that barring same-sex marriage is like barring interracial marriage. The literature ${ }^{84}$ devoted to it uses the U.S. Supreme Court decision in Loving v. Virginia, ${ }^{85}$ striking down anti-miscegenation laws then in force in 16 states as violative of equal protection and due process guarantees ${ }^{86}$ as support for the view that arguments against samesex marriage suffer from the same sectarian reasoning offered in, and rejected by, the Court

As put wonderfully by F.A. von Hayek:

The rule of law is therefore not a rule of law, but a rule concerning what the law ought to be, a metalegal doctrine or a political ideal. It will be effective only in so far as the legislator feels bound by it. In a democracy this means that it will not prevail unless it forms part of the moral tradition of the community, a common ideal shared and unquestioningly accepted by the majority.

The Constitution of Liberty (Chicago: University of Chicago Press, 1960) at 206.

Our legal tradition differentiates between the branches in terms of the source and nature of limited authority. The judicial branch is constrained by text and tradition. The legislative branch, on the other hand, is limited initially by tradition alone and only subsequently, at the election of citizens, by judicial review based on a constitutional instrument such as the Charter or, as in Roncarelli v. Duplessis, [1959] S.C.R. 121, on tradition alone. It is this distinction that gives purchase to Dicey's view of parliamentary sovereignty.

See e.g. David Orgon Coolidge, "Playing the Loving Card: Same-Sex Marriage and the Politics of Analogy" (1998) 12 BYU J. Pub. L. 201; Robert F. Drinan, "The Loving Decision and the Freedom to Marry" (1968) 29 Ohio St. L.J. 358; Daniel R. Gordon, "The Ugly Mirror: Bowers, Plessy and the Reemergence of the Constitutionalism of Social Stratification" (1993) 19(1) J. Contemp. L. 21; Andrew Koppelman, "The Miscegenation Analogy: Sodomy Law as Sex Discrimination" (1988) 98 Yale L.J. 145 and "Same-Sex Marriage and Public Policy: The Miscegenation Precedents"(1996) 16 Quinnipiac L. Rev. 105; Josephine Ross, "The Sexualization of Difference: A Comparison of Mixed-Race and Same-Gender Marriage" (2002) 37 Harv. C.R.-C.L. L. Rev. 255; and Mark Strasser, "Family, Definitions, and the Constitution: On the Miscegenation Analogy" (1991) 23 Suffolk U.L. Rev. 981. On the anti-miscegenation laws themselves, see Robert J. Sickels, Race, Marriage and the Law (Albuquerque: University of New Mexico Press, 1972); Rachel F. Moran, Interracial Intimacy: The Regulation of Race and Romance (Chicago: University of Chicago Press, 2001); and Karen M. Woods, "A 'Wicked and Mischievous Connection': The Origins of Indian-White Miscegenation Law" (1999) 23 Legal Stud. Forum 37. 388 U.S. 1 (1967).

Citing its earlier judgment in Hirabayashi v. United States, 320 U.S. 81 (1943) at 100, the Court described the laws, and the sectarian arguments proffered in support of them, as "odious to a free people whose institutions are founded upon the doctrine of equality" (ibid. at 11). 
in Loving, ${ }^{87}$ and are therefore, equally violative of equality and due process. ${ }^{88}$ Of course, if the only arguments against same-sex marriage are sectarian, then opposing the legalization of same-sex marriage is invidious in a fashion no different from supporting antimiscegenation laws: each is a fundamental assault on equality, and neither has any rhyme or reason beyond sectarian commitments which would foist one's own diseased, personal morality on the whole of the polity.

Now, disposing of this argument is especially important in the present Canadian debate because the Halpern Court appears to endorse the analogy:

If marriage were defined as "a union between one man and one woman of the Protestant faith", surely the definition would be drawing a formal distinction between Protestants and all other persons. Persons of other religions and persons with no religious affiliation would be excluded. Similarly, if marriage were defined as "a union between two white persons", there would be a distinction between white persons and all other racial groups. In this respect, an analogy can be made to the anti-miscegenation laws that were declared unconstitutional in Loving $v$. Virginia ... because they distinguished on racial grounds. ${ }^{89}$

Happily, disposal is not difficult because there exists a reason of principle ${ }^{90}$ on which to distinguish classifications based on religion and race from classifications based on sex, at least so far as the capacity to marry is concerned.

Directly put, the reason is this: while race and religion are irrelevant to one's capacity to occupy the offices "husband" and "wife," sex is not For those offices, as constituted by cultural practice and recognized at law, are oppositely sexed offices. ${ }^{91}$ If this reason is persuasive, then the racial analogy cannot secure the claim of inequality against the law's continuing to recognize the opposite sex nature of the statuses of husband and wife; and, in that event, what Eskridge elsewhere terms "the race card"92 turns out to be no trump at all.

The Court quoted the State of Virginia (ibid. at 3) which offered the following: "Almighty God created the races white, black, yellow, malay and red, and he placed them on separate continents.... The fact that he separated the races shows that he did not intend for the races to mix."

Eskridge, for instance, argues that since the Loving Court struck down Virginia's ban on interracial marriage because the law's classification was premised on an ideology of white supremacy, the courts should now strike down the ban on same-sex marriage because it is premised on an ideology that is at once sexist and heterosexist (supra note 50 at 159-61). Halpern, supra note 4 at para. 70.

*) Part IV of this comment provides another reason of principle which has the same effect but whose ambition is greater since it locates the principle in the normative theory of the liberal state.

Richard F. Duncan makes a point somewhat similar to mine:

Because race is irrelevant to what makes a relationship a marriage, it was immoral and unconstitutional for Virginia to forbid interracial marriages. However, unlike Virginia's racist restriction on marriage, the dual-gender requirement is based upon the inherent sexual complementarity of husband and wife.

See "From Loving to Romer: Homosexual Marriage and Moral Discernment" (1998) 12 BYU J. Pub. L. 239 at 251. See also Lynn D. Wardle, "Legal Claims for Same-Sex Marriage: Efforts to Legitimate a Retreat from Marriage by Redefining Marriage" (1998) 39 S. Tex. L. Rev. 735 at 752-53. 
In my view, it will only persuade if one is prepared, as was the Court in $\mathrm{Baehr},{ }^{93}$ to declare diseased and sectarian any argument from legal history and cultural tradition and practice. Yet, such a declaration is costly since it raises and depends upon a declaration concerning the sovereignty of the state over the whole of social life, its history, and the future of its practices. Part IV of this comment is devoted to persuading that such a declaration is not one that any branch of a liberal state - legislative, executive, and judicial alike - can properly make.

\section{THE AFFIRMATION OF ORDINARY LIFE}

Recall the comment from Eskridge: "[ $t$ ]he more difficult claim to refute is the normative one, that marriage ought to be different-sex by definition." 94 My purpose in this comment has been to make just such a normative argument against the recognition of same-sex unions as marriage: I have aimed to convince that marriage is indeed different-sex, and that a liberal state has no authority over marriage so understood. Parts II and III were devoted to the first purpose - to showing that the cultural practice we know as marriage, and the law of marriage which recognizes that practice, disclose marriage to be opposite-sex. This part is devoted to the second purpose - the limits of state authority. My first concern will be to articulate the relationship that ought properly to obtain between a liberal state and the institutions, particularly marriage, that together comprise what is known to liberal theory as civil society and to those of us who live in liberal society as ordinary life. I shall then assess

Baehr v. Lewin, 852 P.2d 44 (Haw. 1993). In Baehr, the Hawaii Supreme Court held that denying marriage licenses to same-sex couples is unconstitutional unless the state can show a compelling reason to do so. In rejecting Singer v. Hara, 522 P.2d 1187 (Wash. Wn. App.), review denied, 84 2d 1008 (1974), in which the Washington Court of Appeal held that denial of a marriage license to a same-sex couple did not offend the state constitution's prohibition against sex discrimination because they "were not denied a marriage license because of their sex," but "because of the nature of marriage itself" (ibid. at 1196), the Baehr Court declared such reasoning as "exercise in tortured and conclusory sophistry" (Baehr, ibid. at 63). The Baehr Court then went on to dismiss the reasoning in Jones v. Hallahan, 501 S.W.2d 588 (1973), [in which the Court of Appeals of Kentucky held that persons of the same sex cannot marry because "marriage has always been considered as the union of a man and a woman" (ibid. at 589)] in a fashion that conflated the racist/sectarian argument in Loving with the argument from cultural practice in Jones:

The facts in Loving and the respective reasoning of the Virginia courts, on the one hand, and the United States Supreme Court, on the other, both discredit the reasoning of Jones and unmask the tautological and circular nature of [the] argument that ... same sex marriage is an innate impossibility. Analogously ... the Virginia courts declared that interracial marriage simply could not exist because the Deity had deemed such a union intrinsically unnatural, and, in effect, because it had theretofore never been the "custom" of the state to recognize mixed marriages, marriage "always" having been construed to presuppose a different configuration. With all due respect to the Virginia courts of a bygone era, we do not believe that trial judges are the ultimate authorities on the subject of Divine Will, and, as Loving amply demonstrates, constitutional law may mandate, like it or not, that customs change with an evolving social order (Baehr, ibid. at 65).

The issue of compelling state interest was resolved in Baehr v. Miike, No. 91-1394-05, 1996 WL 694235 , in which the First Circuit Court of Hawaii held that the sex-based classification in the Hawaii marriage statute was unconstitutional and enjoined the state from denying a marriage license solely because the applicants were of the same sex. This decision was subsequently reversed by the Hawaii Supreme Court, without opinion, after the passage (ratified 3 November, 1998) of the following amendment to the Constitution of the State of Hawaii: "The legislature shall have the power to reserve marriage to opposite-sex couples," 950 P.2d 1234 (1997). 
the performance of the Canadian state in Halpern against that articulation with a view to condemning its performance as an illegitimate exercise in social engineering. ${ }^{95}$

\section{A. Civil Society}

John Rawls speaks of "the "background culture' of civil society": "[t]his is the culture of the social, not of the political. It is the culture of daily life, of its many associations: churches and universities, learned and scientific societies, and clubs and teams, to mention a few."96 This understanding of the place of ordinary life as beyond politics - as a realm of selfordering social activity and formation independent of control by the state ${ }^{97}$ - is ancient, ${ }^{98}$

y5 Due to the constraints placed on this comment, I can here offer only a sketch of these arguments. I intend to pursue these matters at greater length in an essay entitled "Against Same-Sex Marriage: Civil Society, Social Engineering, and the Limits of Liberal Law" [forthcoming].

\% John Rawls, Political Liberalism (New York: Columbia University Press, 1993) at 14; see also 382-83. Though Rawls does not mention them - and though the exact contours of the concept of civil society, like all important concepts, remain subject to debate - marriage and family are generally thought to be institutions that reside at the heart of civil society: see e.g. Linda C. McClain \& James E. Fleming, "Foreword: Legal and Constitutional Implications of the Calls to Revive Civil Society" (2000) 75 Chicago-Kent L. Rev. 289 (defining civil society as "a realm between the individual and the state, including the family and religious, civic, and other voluntary associations") Anne Showstack-Sassoon, "Family, Civil Society, State: Is Gramsci's Concept of 'Societa Civile' Still Relevant?" (1998) Philosophical Forum 206; and Will Kymlicka, Contemporary Political Philosophy: An Introduction (Oxford: Clarendon Press, 1990) at 250-257. For an analytical history of the concept, see John Ehrenberg, Civil Society: The Critical History of an Idea (New York: New York University Press, 1999); and Michael Walzer, "The Concept of Civil Society" in Michael Walzer, ed., Toward a Global Civil Society (Providence, RI: Berghahn Books, 1995) 7.

${ }_{97}$ Put well by Ernest Gellner:

Civil Society is that set of diverse non-governmental institutions which is strong enough to counterbalance the state and, whilst not preventing the state from fulfilling its role of keeper of the peace and arbitrator between major interests, can nevertheless prevent the state from dominating and atomizing the rest of society

"The Importance of Being Modular" in John A. Hall, ed., Civil Society: Theory, History, Comparison (Cambridge: Polity Press, 1995) at 32. Elsewhere, Gellner indicates that "civil society is a cluster of institutions and associations strong enough to prevent tyranny, but which are, nevertheless, entered freely." See Conditions of Liberty: Civil Society and Its Rivals (London: Hamish Hamilton, 1994) at 193.

98 The ancients distinguished between two realms of human association: polis, the political, was, they thought, formed - constructed - for the purposes of communal living; oikia, in contrast, was thought natural and prior to the political and concerned with the ordinary, daily needs of life. Arendt puts the matter thus:

According to Greek thought, the human capacity for political organization is not only different from but stands in direct opposition to that natural association whose center is the home (oikia) and the family. [...] The realm of the polis ... was the sphere of freedom, and if there was a relationship between these two spheres [the polis and the oikia], it was a matter of course that the mastering of the necessities of life in the household was the condition for freedom of the polis. (Supra note 3 at 24-25, 29).

Which is to say, political freedom in the public sphere is different from, anterior to, and dependent upon social freedom in the private sphere. Incidentally, when we speak of civil rights, we speak as did the ancients: "Civil rights are ... prior and independent of law. Laws are enacted to protect civil rights; failing enactment, the law is said to deny them. They seem, therefore, not to depend on the law for their existence, but only for their recognition" (Lloyd L. Weinrib, "What Are Civil Rights?" (1991) 8 Social Philosophy \& Policy 1 at 2). 
continues to inform debate about the limits of state power, ${ }^{99}$ and more to the present point, informs at its very core what is known in the Anglo-American tradition as the Rule of Law.

Philosophical and political liberalism descends from two commitments, one to moral equality (that each of us is equal despite the manifold differences between us and that we therefore deserve to be treated equally), ${ }^{100}$ and another to "the priority of social life over politics." 101 These two commitments are related at several levels of understanding, most importantly in the following way: that political equality will be preserved only if the power of the state to act against equality is constrained by institutional arrangements. Constraint of that sort requires, inter alia, the preservation of social freedom as a locus or site from which the denizens of the state, in their capacity as free persons and not as citizens, might oppose and criticize political power. ${ }^{102}$ The Rule of Law is the institutional architecture of the liberal state, just because it devotes the state itself to the constraint of power, especially its own. That is, the Rule of Law legitimates state power to the extent that it is exercised in service to equality and to equality's precondition: freedom in the social realm. Implicit, therefore, in the Rule of Law are norms concerning the proper relationship of the liberal state to the institutions and practices of social life.

\section{B. Liberal State ANd Civil Society}

Catharine A. MacKinnon wisely contends that jurisprudence, which is to say disciplined reflection about law, is finally about the "relation between law and life." ${ }^{103}$ Reflection about law must be about this matter because, as constituted by the Rule of Law, law is the practice and tradition whose point it is to establish the limits of the state's authority over the lives led by those subject to its rule. But law is not neutral in this regard. It proceeds rather with the attitude, again bred of the Rule of Law, that the law's claims on lives is limited because the liberal state, whose laws they are, is itself a limited state. The limitations that define the liberal state subsist in the nature of its relationship with individual lives and the social forms through which those lives are lived. Shortly put, the liberal state is a state that defers to the self-ordering of individuals and of society.

In the legal community no less than any other. See for example, "Symposium on Legal and Constitutional Implications of the Calls to Revive Civil Society" (2000) 75 Chic.-Kent L. Rev. 289-612. For full elaboration, see David Johnston, The Idea of a Liberal Theory: A Critique and Reconstruction (Princeton: Princeton University Press, 1994) at 18-27. Kymlicka, supra note 96 at 257.

102 Which is to say: "[p]olitical liberalism ... aims to maintain a distinction between the point of view of people as citizens and the various ethical points of view people take as members of families and other nonpublic associations" (John Tomasi, Liberalism Beyond Justice: Citizens, Society, and the Boundaries of Political Theory (Princeton: Princeton University Press, 2001) at 41). Incidentally, Hart's famous insistence on the separation of law and morals is best explained in terms of this liberal commitment: "the certification of something as legally valid" must not be thought "conclusive of the question of obedience," because that matter falls properly to individual "moral scrutiny" and to the "sense that there is something outside the official system by reference to which the individual must solve his problems of obedience" (H.L.A. Hart, The Concept of Law, (Oxford: Clarendon Press, 1961) at 206). 
As regards individuals, the law understands that only when an individual's conduct causes real harm to others has the state warrant to claim authority over that life. ${ }^{104}$ As regards the institutions and practices of civil society, the situation is more complex. With a singular and rare exception, a liberal state is required, at the cost of its authority, to exhibit deference to the authority of civic institutions, traditions, and practices. Through this deference, the liberal state at once affirms its own limitations and the ordinary lives of those who, in their capacity as citizens, are its subjects. Deference to, and affirmation of, ordinary life may take either of two forms: the state may simply leave alone the institutions, practices, and traditions which together constitute the lifeworld of its subjects, or it may instead seek to support them by enacting laws that recognize the importance of their contribution to the life of political community. In the latter case, recognition cannot include reformation, nor must it be confused with constitution. Instead, reformation falls properly to the institutions and practices of civil society themselves. If over time, institutions and practices do reconstitute themselves, only then may the state incorporate such changes into those laws of recognition, if any, that apply to them.

The task of social reconstruction, as indicated, is only very rarely the state's. A liberal state may only exceed recognition in its relations with standing social practices, institutions, and traditions when the continuance of a particular institution, practice, or tradition compromises the liberal credentials of the state and so its continuance as a liberal state. This will be the case only where an institution, tradition, or practice is perniciously opposed to moral equality, that core value of liberal politics. In such a case - and antebellum slavery in America is the paradigmatic instance - a liberal state has a positive obligation not to reform, but to abolish the institution. But this case will be exceptional, simply because in mature political communities (and here one excludes antebellum America, its accomplishments notwithstanding), social life itself will exhibit liberal values. ${ }^{105}$ Under no view of the matter would the practices of an institution such as (traditional) marriage qualify the state, through any of its branches, to act beyond recognition. Indeed, according to most views, marriage and family as traditionally practised are essential to the flourishing and continuance of liberal political culture. ${ }^{106}$

\section{EXCESS: SOCIAL ENGINEERING}

When a state exceeds the boundaries that define its proper relationship to civil society, when it forsakes affirmation and instead takes the institutions and practices of civil society as objects subject to its legislative or curial surveillance or reform, it may be said to have involved itself in social engineering. Before addressing the performance of the Canadian state in Halpern, it is important to be precise as regards the methodology by which a professedly liberal state may, by reason of perfectionist zeal or expansionist ambition, abandon its liberal credentials in this way.

Famously put by John Stuart Mill in his essay On Liberty (1859) (Harmondsworth: Penguin, 1974). See Ronald Dworkin, "Liberal Community" (1989) 77 Calif. L. Rev. 479; Alan Ryan, "The Liberal Community" in John W. Chapman \& Ian Shapiro, eds., Democratic Community (New York: New York University Press, 1993) 91; and Tomasi, supra note 102 passim.

See e.g. Jennifer Roback Morse, "No Families, No Freedom: Human Flourishing in a Free Society" (1999) 16 Social Philosophy \& Policy 290; and Nancy F. Cott, Public Vows: A History of Marriage and the Nation (Cambridge, MA: Harvard University Press, 2000). 
Like Hayek ${ }^{107}$ and Burke, ${ }^{108}$ one may believe that social institutions are more the consequence of gradual growth and adaptation than of any deliberate design or plan. Alternatively, one may believe that social institutions are properly the object of planning and redesign to make them better achieve whatever ends they are thought to serve. In the latter case, one believes in the propriety and possibility of social engineering. ${ }^{109}$

Social engineers do not affirm ordinary life. They deny it. For them, ordinary life is a problem in need of a solution, and they are therefore moved to re-design extant social practices and to erect new ones. In all of this, the lived lives of "human beings serve as raw material." ${ }^{110}$ The twentieth century will be remembered as the age of social engineering par excellence, both because the dreams of re-engineering the social - fascist, communist, nazi dreams especially but not only included - were then so grand and utopian and so full of conviction, and because no amount of ordinary human suffering was thought too high a price to pay for making the world whole again. ${ }^{11}$

I do not wish to draw a comparison between these projects and the many projects of social engineering now afoot in liberal states, including the one being pursued by the Canadian state in Halpern. I do, however, wish to refer very briefly to that history as a way of defining the methodology of states intent on engineering the social. I shall then offer a characterization of projects of that sort in liberal states, before proceeding to a consideration of the performance in Halpern.

The lawyers, doctors, academics, and ideologues of Hitlerite Germany had a term of political art for it, Gleichschaltung: in order to achieve "a global remodelling of society in accordance with racial criteria," 12 it would be necessary, indeed essential, to "co-ordinate" each and every social institution, practice, and tradition with those norms. ${ }^{113}$ And therein lies

Freidrich A. von Hayek, The Road to Serfdom (1944) (Chicago: University of Chicago Press, 1994). Edmund Burke, Reflections on the Revolution in France (1790) ed. J.G.A. Pocock (Indianapolis: Hackett Publishing, 1987).

See Jon Alexander \& Joachim K.H.W. Schmidt, "Introduction: Social Engineering - Genealogy of a Concept" in Adam Podgórecki, Jon Alexander \& Rob Shields, eds., Social Engineering (Ottawa: Carleton University Press, 1996) 1; and Michael T. Hayes, The Limits of Policy Change: Incrementalism, Worldview, and the Rule of Law (Washington: Georgetown University Press, 2001). For an insightful intellectual history of this worldview, see Zygmunt Bauman, Legislators and Interpreters: On Modernity, Post-Modernity, and Intellectuals (Ithaca: Cornell University Press, 1987). On law and the notion of social engineering, see Linus J. McManaman, Social Engineering: The Legal Philosophy of Roscoe Pound (Atchison: Abbey Student Press, 1953); and Robert E. Rodes, "Law, Social Change and the Ambivalence of History" (1975) 49 Proceedings \& Addresses of the American Catholic Philosophical Association 164.

Alexander \& Schmidt, ibid. at 1 .

On the latter, see especially the pioneering work of R.J. Rummel, including Death by Government $(\mathrm{New}$ Brunswick, NJ: Transactions Publishers, 1994); and Statistics of Democide: Genocide and Mass Murder Since 1900 (Charlottesville: Centre for National Security Law, 1997).

Michael Burleigh \& Wolfgang Wippermann, The Racial State: Germany, 1933-1945 (Cambridge: Cambridge University Press, 1991) at 304.

Neither the legal community nor marriage and family were of course excepted from co-ordination. Concerning the former, see Ingo Muller, Hilter's Justice: The Courts of the Third Reich, trans. by Deborah Lucas Schneider (Cambridge, MA: Harvard University Press, 1991); Konrad H. Jarausch, The Unfree Professions: German Lawyers, Teachers, and Engineers, 1900-1950 (New York: Oxford University Press, 1990); and Michael Stolleis, The Law under the Swastika: Studies on Legal History in Nazi Germany, trans. by Thomas Dunlap (Chicago: University of Chicago Press, 1998). For the 
the twentieth century's lesson for us in these matters: when states seek to engineer ordinary life, they necessarily do so by co-ordinating the institutions and practices of ordinary life to state-articulated and state-enforced norms.

Contemporary liberal states of course involve themselves in a host of engineering projects that range in their focus from individual health to common civility. ${ }^{114}$ However, the most important ones - those that qualify as instances of what I shall here term "the constitutionalism of the social" - deploy the methodology of social engineering precisely and depend upon it entirely. By "constitutionalism of the social," I mean to refer to the extension of judicial review from its proper focus on legislation to a progressivist concern with social conditions. Equality is the focus of this concern and the medium of this extension. Indeed, "[d]ealing with the effects of inequality has become a euphemism for current liberalism's assault on what the old liberals called civil society." 115 The practice is not complicated: the state articulates norms of equality and then imposes those norms, either legislatively or curially, on social life. It requires only the slightest pretext to do so. And because there is indeed much "public acceptance of these assaults," there is no shortage of interest groups to urge legislators on or to present themselves to judges as litigants. ${ }^{116}$ That this at once renders persons clients of the state and subjects the whole of social life to potential state surveillance and management are matters to which I will return in the conclusion. I want first, however, to assess the Halpern decision as an instance of this phenomenon.

\section{The Canadian STATE IN HaLPERN}

As part of its submissions on whether the opposite-sex "requirement" satisfied the Oakes 117 test, the Attorney General of Canada submitted (as redacted by the Court) that "[c]hanging the definition of marriage to incorporate same-sex couples would profoundly change the very essence of a fundamental societal institution." 18 In rejecting this submission - "[w]e reject the AGC's submission as speculative"119 - the Court reveals much about its understanding of its mandate. For with this, the Court is not contesting that it is changing a "fundamental societal institution"; rather, it is dissenting from the Attorney General's assessment of the significance or, if you will, the quantum, of the change. Which is to say, the Court simply presumes that it has authority over the social.

Evidence of this understanding is on display throughout the judgment. For instance, in framing the case - "this case is ultimately about the recognition and protection of human

latter, see Lisa Pine, Nazi Family Policy, 1933-1945 (Oxford: Berg, 1997); Otto Kirchheimer, "The Legal Order of National Socialism" in Otto Kirchheimer, Politics, Law, and Social Change: Selected Essays (New York: Columbia University Press, 1969) 88; and Stolleis, ibid. at 71-72.

114 See in this regard Alexander \& Schmidt, supra note 109.

Iis Paul Edward Gottfried, After Liberalism: Mass Democracy in the Managerial State (Princeton: Princeton University Press, 2001) at 25. For an insightful marxist analysis of "the law's role in policing civil society," see Mark Neocleous, Administering Civil Society: Towards a Theory of State Power (Houndmills: Macmillan, 1996) at 164.

116 Gottfried, ibid.

$117 \quad$ R. v. Oakes, [1986] 1 S.C.R. 103.

118 Halpern, supra note 4 at para. 133.

$119 \quad$ Ibid. at para. 134. 
dignity and equality in the context of the social structures available to conjugal couples in Canada" 120 - the Court straightaway asserts its authority over the social. So too in defining marriage: since marriage is the institution through which "society publicly recognizes expressions of love and commitment," 121 and since the Court presumes to judge the qualities and terms and conditions of that recognition, it per force takes the social to be subordinate to its own authority. Again, in summing up, at the conclusion of its s. 15(1) deliberation, the Court opines that "[i]n this case, same-sex couples are excluded from a fundamental societal institution - marriage. The societal significance of marriage ... cannot be overlooked. Indeed, all of the parties are in agreement that marriage is an important and fundamental institution in Canadian society." 122 I shall not go on. Suffice it to say that Halpern proceeds from, and its result is only intelligible in terms of, the proposition that the judicial branch of the Canadian state has legitimate authority over the institutions and practices of civil society.

On this understanding, it becomes the Court's aim to co-ordinate the institution of marriage to the norms of equality articulated by the judicial branch of the Canadian state since 1982. This it does with dispatch: first, this "fundamental societal institution" is found to offend those equality norms; ${ }^{123}$ next, that offense is found to be unacceptable in, because it is unreasonable to, a society with those norms; ${ }^{124}$ and then - in the moment of climax in the coordination ritual - the institution is changed to fit state norms. ${ }^{125}$

But that does not conclude the performance. The Halpern Court also broadcasts that any social institutions might properly be subject to the curial gaze of the Canadian state. I refer to its espousing of what it terms "this country's jurisprudence of progressive constitutional interpretation." 126 Under this view of constitutionalism, the reach and appetite of judicial review is potentially endless and by definition always unknowable since "activities ... not previously ... included" just might be included in some future case. ${ }^{127}$

We witness in Halpern a nearly-perfect instance of social engineering: the motivation (equality), the practice (coordination), and the ambition (limitless) are each paradigmatic. And, with this, we witness as well the Canadian state abandoning its proper place as a liberal governor. In the place of affirmation, it offers assessment and correction. And, in so doing, it is at once denying the value of social life and history and proclaiming, and then imposing, its own view of the lifeworld on those subject to its power.

\section{Conclusion}

As indicated previously, I wish to conclude this piece with certain brief comments on what Halpern signals for the practices of both marriage and liberal governance in Canada; on the attitude of the Court in Halpern (as perhaps indirect evidence of the latter); and on what in 
my view would constitute, under certain conditions, a proper response to homosexual unions by a liberal state.

\section{A. MARRIAGe AND GOVERNANCE}

Contrary to what is apparently the Court's own understanding, ${ }^{128}$ the result in Halpern is no mere redefinition. MacIntyre counsels "that practices always have histories and that at any given moment what a practice is depends on a mode of understanding it which has been transmitted often through many generations"; and he concludes that sustaining practices means "sustain[ing] relationships with the past." ${ }^{29}$ By eliminating status from marriage and by reconceiving it as simply the recognition of an already extant relationship, the Halpern Court has broken the connection of marriage to its past. I have already argued that an institution at once unmade and remade in this fashion is effectively abolished, ${ }^{130}$ and that the new marriage on offer from the state diminishes the lifeworld because it makes of marriage a nullity morally, a meaningless event that offers us no human relationship that would not be there without it. I want now to suggest that the state's chiselling away at marriage and the family has, with Halpern, become conquest.

It is everywhere accepted ${ }^{131}$ that, beginning in the nineteenth century, the liberal state has progressively intervened ${ }^{132}$ in marriage and the family. What is contested is the culminative significance of these legislative and curial endeavours. ${ }^{133}$ I cannot enter that debate here. Instead, I wish briefly to argue that, however the history of family law is construed (and I suspect that no over-arching narrative of the matter will be convincing), the turn in Halpern, wherever it occurs, signals the complete and final politicization of marriage.

Halpern makes of marriage a legal form. That is, by putting aside both the history of the institution and its place and meaning in ordinary moral and social commerce, the Court

$128 \quad$ Ibid. at para. 108.

129 Supra note 45 at 221.

130 Supra note 56 and accompanying text. Accord: Wardle, supra note 91 at 757 , arguing that the "desired transformation is so fundamental that it would constitute a basic replacement of the essential concept of marriage."

131 In addition to Stone, supra note 24 and Gillis, supra note 24, see Stephen Cretney, Law, Law Reform and the Family (Oxford: Clarendon Press, 1998); June Carbone, From Partners to Parents: The Second Revolution in Family Law (New York: Columbia University Press, 2000); and Michael Grossberg, Governing the Hearth: Law and the Family in Nineteenth-Century America (Chapel Hill: University of North Carolina Press, 1985). For commentary on recent Canadian experience, see Nicholas C. Bala and Rebecca Jaremko Bromwich, "Context and Inclusivity in Canada's Evolving Definition of the Family" (2002) 16 Int'l J. L. Pol'y \& Fam. 145.

132 On the meaning(s) of legal intervention in these matters, see Laurence D. Houlgate, "What is Legal Intervention in the Family? Family Law and Family Privacy" (1998) 17 Law \& Philo. 141.

133 See e.g. Elizabeth Beck-Gernsheim, "On the Way to a Post-Familial Family: From a Community of Need to Elective Affinity" (1998) 15 Theory, Culture \& Society 53; Sandra Berns, "Folktales of Legality: Family Law in the Procedural Republic" (2000) 11 Law \& Crit. 1; John Dewar, "Family Law and Its Discontents" (2000) 14 Int'l J.L. Pol'y \& Fam. 59; Paul Ginsborg, "Measuring the Distance: The Case of the Family, 1968-2001" (2002) 68 Thesis Eleven 5; Alice Hearst, "Constructing the Family in Law and Policy" (1997) 22 Law \& Soc. Inquiry 131; Martha Minow, "“Forming Underneath Everything That Grows': Toward a History of Family Law," (1985) Wis. L. Rev. 819; Carl E. Schneider, "Moral Discourse and the Transformation of American Family Law" (1985) 83 Mich. L. Rev. 1803; Lee E. Teitelbaum, "Family History and Family Law" (1985) Wisc. L. Rev. 1135; and Brian T. Trainor, "The State, Marriage and Divorce" (1992) 9:2 J. of Applied Philosophy 135. 
reduces marriage entirely to law. With this, marriage is not only fully politicized, but, in a very real sense, becomes territory conquered by state law. ${ }^{134}$ This conquest comes at a very great cost, both for liberty and for the plurality that is its test and expression.

These consequences do not rely on the view that the colonization of marriage is the ultimate bite out of civil society, though it is indeed a bite so intimate that the whole of civil society might now be entertained - by ideologues, legislators, judges, and citizens alike as properly on the menu of state surveillance and management. Rather, they attach to and flow from the nature of legal form itself. ${ }^{135}$ For much follows from the claim that the law is constitutive of any set of social relations. First, the statuses of which those relations are composed become dependent upon the sufferance of the state. Second, and more importantly, the persons who occupy those positions become not just clients of the state, but the bearers and reproducers of state norms as well. With all of this, the state becomes the arbiter of the very being of its subjects and its subjects become for it (and, to the extent that they consciously submit their social status to the state, for themselves as well) the media - "the raw material" 136 — for the institution of state norms.

Liberty and difference cannot long survive this view of law and life. Given the argument so far, the case for the former should be clear: the politicization of social life in this juridified fashion enlarges the state's power to discipline the lives and lifeworld of persons and so, without more, diminishes liberty. ${ }^{137}$ The argument for the second rests on a consequence certain to the enlargement of state power in this way, namely that state norms for the performance of the social have a homogenizing and levelling effect. This is inevitably so, for once the lifeworld is orchestrated by the state, certain performances become standard and other performances deviant and disvalued.

Incidentally, Rawls appears to have recognized that this would be the result of subjecting marriage and family to state norms; (A Theory of Justice (Cambridge, MA: Belknap Press, 1971) at 151). For a rejoinder to Rawls, see Michael J. Sandel, Liberalism and the Limits of Justice, 2nd ed. (Cambridge: Cambridge University Press, 1998) at 33.

Though constitutive theory has been sometimes pursued by liberal scholars, its proper home is marxist. For the former, see e.g. Robert M. Cover, "Foreword: Nomos and Narrative" (1983) 97 Harv. L. Rev. 4; James Boyd White, "Rhetoric and Law" in James Boyd White, Heracles' Bow: Essays on the Rhetoric and Poetics of Law (Madison: University of Wisconsin Press, 1985) 28; and - curiously and only this once - Dworkin, "Preface" Law's Empire, supra note 1 at vii. For the latter, see e.g. Ruth Fletcher, "Legal Forms and Reproductive Norms" (2003) 12 Social \& Legal Studies 217; and Neocleous, supra note 115. Alexander \& Schmidt, supra note 109 at 1.

That this result goes hand in glove with juridical reception of the social is a matter often overlooked and not least by most proponents of same-sex marriage. For instance, Petchesky \& Zaretsky have each argued that the juridical recognition of women in the nineteenth century implicated an expanded state and medical control over the reproductive and sexual conduct of women. See Rosalind Pollack Petchesky, Abortion and Women's Choice: The State, Sexuality, and Reproductive Freedom (New York: Longman, 1984); and Eli Zaretsky, "The Place of the Family in the Origins of the Welfare State" in Barrie Thorne \& Marilyn Yalom, eds., Rethinking the Family: Some Feminist Questions (New York: Longman, 1982) 188. Martha Minow makes the same point concerning the effect of rights of children in expanding judicial power and state control over the lives of both children and adults; "Interpreting Rights: An Essay for Robert Cover" (1987) 96 Yale L.J. 1882, n. 82. 


\section{B. THE NARRATIVE TONE AND TEMPER OF HALPERN}

Halpern will stand in legal history, along with its like-minded fellows, for the pronouncement that a fundamental social institution, as practiced from time out of memory, is and always has been unjust. So startling and so grand a proclamation would otherwise seem to warrant some humility, some concession of understanding and regret to those men and women who have laboured under the opposite view. One finds none of this in the judgment. On the contrary, the structure is summary and formulaic, and the tone intemperate and, indeed, often insolent. ${ }^{138}$ I want to suggest that none of this is accidental, and that a narrative attitude and strategy of this sort inheres, at least as a risk, in the very practice of the state's claiming sovereignty over social life.

I have argued that the constitutionalism of the social is necessarily monochromatic and homogenizing. It is also inherently monologic. This is so in equal measure because state norms, including equality in particular, are understood by the interventionist state to be beyond reproach, and because, so understood, those norms become cause for the activist motive sincerely held by many state actors of redeeming any and every part of life somehow tainted by contrary norms. It is just this assumption and this motive that makes according respect and honour to contrary views so difficult. Because the state is right and because it wills only well on its subjects, its discourse is one that tends always to take other views merely as grist for its self-validation.

\section{ReCognizing SAME-SeX Unions}

I come then to the matter of how a liberal state ought properly to respond to same-sex unions. Now, it could properly - as it could with marriage - simply remain silent on the matter. For reasons already recounted, this response is in my view the better one, at least for those who value the long-fought-for, and finally accomplished, independence of homosexuality from law and the contributions of a free gay and lesbian culture to the lifeworld. ${ }^{139}$ But, assuming for the sake of argument that the lesbian and gay rights movement - focused as it is on state recognition ${ }^{140}$ — will lead the state to wish to do something, I want to argue that the state may properly pursue the alternate course of recognition only if two conditions are met. This argument proceeds on the understanding that recognition would take the form of civil union or registered domestic partnership legislation.

The conditions are these: first, that same-sex union has established itself as a social institution, that is, that it is widely practiced among, and endorsed by, members of the gay and lesbian community; and second, that recognition does not reduce to, or otherwise

For example, see the Court's repeated, self-satisfied denigration of what it terms "natural procreation" (supra note 4 at paras. 93,122,130); its off-hand dismissal of arguments concerning consequences as "speculative" (ibid. at para. 134); or its summary defense of its decision not to allow a period of suspension (ibid. at para. 153).

139) Concerning the former, see Carl F. Stychin, Law's Desire: Sexuality and the Limits of Justice (London: Routledge, 1995; and for the latter, see Michael Warner, ed., Fear of a Queer Planet: Queer Politics and Social Theory (Minneapolis: University of Minnesota Press, 1993).

140 See Miriam Smith, Lesbian and Gay Rights in Canada: Social Movements and Equality-Seeking, 19711995 (Toronto: University of Toronto Press, 1999); and Barry D. Adam, The Rise of a Gay and Lesbian Movement, rev. ed. (New York: Twayne Publishers, 1995). 
implicate, social engineering. The first condition is meant to respect the integrity of the homosexual community as a whole, especially given the law's dishonourable history in that regard. The second is meant to prohibit the state from rejoining that history under the guise of benevolence.

In my view, there are real questions concerning whether either of these conditions is met. So far as the first is concerned, gay and lesbian literature is replete with contestations over the desirability of same-sex marriage. ${ }^{141}$ And so far as the second is concerned, leading proponents argue that same-sex marriage is desirable because necessary to change gay and lesbian culture. ${ }^{142}$ Because these questions remain - and because it does not fall to the liberal state to domesticate transgressive practices ${ }^{143}$ nor to impose a social practice on any community - the propriety of recognition legislation is itself seriously at question.

Most famously by Claudia Card, "Against Marriage" in John Corvino, ed., Same Sex: Debating the Ethics, Science, and Culture of Homosexuality (London: Rowman \& Littlefield, 1997) 317. Eskridge, supra note 50 at $51-85$ provides a summary of the ongoing debate.

Sullivan, for instance, thinks same-sex marriage desirable because it will serve as "anchor ... in the maelstrom of sex and relationships to which we are all prone," because it "provides a mechanism for emotional and economic security" and "role models for young gay people," because it "could help bridge the gulf often found between homosexuals and their parents ... [and] to heal the gay-straight rift," and because it will enable gays and lesbians to feel that "their emotional orientation [is] not merely about pleasure, or sin, or shame, or otherness" (supra note 66 at 84, 85, 86, 87). For his part, Eskridge supports same-sex marriage because, in his view, it would have a "civilizing effect" on gays and lesbian and the rest of society, because it would lead to a "greater degree of domestication" among gays and lesbians, and because its "commitment device" would reduce both promiscuity among gays and lesbians and consequently the risk to the exposure to HIV-infection; supra note 50 at 111-12. That these arguments call for the manipulation of the lifeworld of homosexuals I should think would be obvious. That they also, in my view, seek to normalize and to tame the transgressive nature of homosexual culture and bleed into self-hatred, are unhappily matters that I cannot pursue here. Incidentally, the Court in Halpern at one point appears to endorse Eskridge's civilizing rational for same-sex marriage: see supra note 4 at para. 134. 